\title{
Development of technologies and processes in environmental management
}

\author{
Daurenbek Mazhitov ${ }^{1}$, Mariia Ermilova $^{2}$,Elena Altukhova ${ }^{2}$, Tatiana Maksimova $^{2 *}$, and \\ Olga Zhdanova ${ }^{2}$ \\ ${ }^{1}$ L.N.Gumilyov Eurasian National University, 010000, 2 Satbayeva st. ,Nur-Sultan, Kazakhstan \\ ${ }^{2}$ Plekhanov Russian University of Economics, 117997, 36 Stremyanny per., Moscow, Russia
}

\begin{abstract}
Environmental management is principally aimed at the formation of ecological productivity, ecological culture and human viability. Development of technologies and processes in environmental management characterized with the principles and items which are specified on the global environmental impact. The very concept of environmental management includes many management problems related to the environmental process as an object of management. Along with governance systems (laws, legislation, rules/regulations, codes and standards etc.), education (awareness raising, capacity building, training, professional development etc.), technology (technologies, and the skills, knowledge and innovation needed to manage those technologies)forms the third and a critical pillar in a policy mix that is needed to tackle environmental problems and aim for sustainability in the long run. Developing technologies that can help solve environmental problems requires a broad range of actions that are to be taken by different "external" stakeholders, besides those that actually develop and operationalize the technologies' private sector companies, universities and research institutions et. al High levels of pollution and gradual reduction of natural resources, inefficient system of economic incentives for environmental activities - in many cases it will be easier for companies to pay fines than to solve environmental problems.
\end{abstract}

\section{Introduction}

Environmental management serves to manage and coordinate environmental protection programs. This direction is relevant today, which is why the main focus is on the essence of environmental management. Environmental management is one part of the overall management system, which has a clear organizational structure and aims to achieve the provisions of the environmental policy through the implementation of environmental programs. The current reality shows that standardized environmental management has become a part of production processes. Because of this, environmental management is widely used in modern enterprises and most of them have set a goal to develop in the right direction in the future. Application of different types of methods and types of

\footnotetext{
*Corresponding author: tatyana_levchenko58@mail.ru
} 
environmental management will allow companies to be flexible in the changing conditions of the legislation and policy of the country in the field of environmental safety, as well as more effective in the organization of production processes and in the emergence of management structural complexes.

The main purpose of studying this direction is to define the main objectives of environmental management as the management of objects and subjects of environmental protection.

Objectives of the study:

1) Comparison of key economic performance indicators, i.e. costs and benefits relative to the environmental costs and benefits of global systems;

2) Define an operational environmental policy criterion, consistent with the higher objectives of the enterprise, which should guarantee freedom of decision-making by the organizational units within their mandates.

3) Develop active public work towards environmental protection.

Ecology is a science that studies the relationship between organisms and their environment. [1].

With regard to the environmental sphere, the category "management may have the right to exist, provided that the content of this organizational and management activity will take into account and optimally coordinate the environmental and economic interests of sustainable use of natural resources. The current system of environmental management requires an in-depth development and understanding of its theoretical foundations, the generalization of the practice of regulation of environmental and economic relations of nature use, development of the concept of environmental management on this basis, the study of the content and specificity of management relations in the environmental sphere [2].

Over the past decade, many international documents have been developed in which the logical interaction between nature and society is linked to the term "environmental development". This term means linking the goals and objectives of social and economic development with the latest requirements to the state of the environment.

The actual aspects of environmental management in the international community include

- Analysis of the development of technologies and processes that reduce the impact on the environment

- The formation of a market for environmental services, taking into account the corresponding development of means of managing this market:

Formation of financial structures to support environmental actions

1. Environmental audit of the level of environmental impact

2. Environmental insurance

3. Changes in the reporting forms for producers' activities

4. The formation of new forms of advertising and trade principles

\section{Literature review}

Professors G.M. Mutanov and others wrote in their article about the new criteria for evaluating eco-innovation projects. The purpose is to develop and propose a graphic model by which to assess the innovativeness, competitiveness, and eco-efficiency of ecoinnovation projects [3].

Researchers S.T. Ziyadin et al. managed about the specific factors in the ecological projects. The economic and mathematical models that form the basis of the toolkit are constructed using the mathematical apparatus of fuzzy logic, which allows for the description of poorly structured knowledge of specialists, as well as their application in 
solving questions about the extent of the impact of the proposed projects on the environment [4].

Sayabek, Z., et al. wrote about prototypes of the models, how it will convince the opponents meanings according the theme of research. For an impactful analysis, the research process adopted here would be the qualitative analysis [5].

Ziyadin S., Dauliyeva G., Kalymbekova Zh., Turlybekova A., Zharaskyzy G. researched An important goal of promoting tourism in the Republic of Kazakhstan is the formation of a socially and environmentally oriented, profitable and competitive tourism industry that is able to supply the needs of tourists with various tourist services, bringing in revenues to the country and newly created jobs, including those defined with tourism in the sectors economy. They mentioned about ecological aspects, environmental factor and described the tourism sphere in the whole.[6]

Burmatova O. P. disclosed the main reasons: weak interest of the Russian enterprises in the implementation of environmental management, among which there is a weak organizational structure of management at the Russian enterprises; narrow understanding of environmental management by the enterprises themselves; low credibility abroad of certificates of environmental management issued by Russian organizations; certain misunderstanding of the importance and necessity of environmental management; weak existing regulatory framework, in which there are no stimulating effects for the implementation of environmental activities, etc. The interrelation of the environmental management system at the enterprises and the principle of the best available technologies is shown and it is concluded that the effective use of one of these management tools is impossible without the establishment of the other [7].

Pirozhnik, I. and M.G. Yasoveev wrote this in the work: Over the past five years, work has been carried out to form a single collection of educational literature on environmental specialties. Russian-Belarusian publishing houses have published a series of textbooks and manuals on environmental education prepared by the authors under the guidance of Professor M.G. Yasaveev, which significantly contribute to the integration of the educational process in the field of ecology and the creation of a unified educational environment of the Union of Belarus and Russia. Currently, intensive work is being done to create joint programs of environmental education for students, masters and postgraduates of Belarusian and Russian universities [8].

A.A. Muzalevskaya has written: The problem of ecological management is one of the priority ones for the motor transport enterprise in the future. Motor transport complex is the main source of environmental pollution in all types of environments. According to various estimates, within the urban areas it accounts for $86-89 \%$ of the contribution to atmospheric air pollution. Vehicles emit about 2 million tons of carbon, nitrogen, sulphur and other harmful substances annually, and plants are able to absorb no more than 10 percent of this volume. However, this is not the only problem. Pollution from motor vehicles covers not only the atmosphere, but also other natural environments: surface water, groundwater and soil. It is of a chemical, physical, landscape and biocenosis nature and covers all stages of the life cycle of the vehicle (production, operation and disposal). Proceeding from the increased ecological danger of motor transport, ecological standards of safety of vehicles, corresponding to the current international requirements, are established at the state level. Control over their observance is based on provision of information on environmental issues to the State Committee on Ecology, Department of Technology and Ecology of the Ministry of Transport of the Russian Federation, statistical and tax authorities. The composition of documents in the environmental documentation of the road transport company is defined in the document approved by the Ministry of Transport of the Russian Federation "Environmental Requirements for Enterprises of Transport and Road Complex of the Russian Federation" [9]. 
Rieseberg, L. H., et al: A simplified target approach to the analysis of data in environmental management based on the theory of ordinal statistics is proposed. Its perspective is demonstrated when solving typical tasks of studying the content of pollutants in natural waters of the industrial region. It is shown that the proposed approach is not only simple and clear, but also allows us to obtain a result with increased reliability in comparison with classical methods of data analysis [10].

Sadovnichy, V. A., et al : Modern industrial-technological development of the society forms a new habitat of an individual, a new way of life, thus having a direct impact on the surrounding reality. The state of the world ecology is currently unstable and is in a state of crisis. According to a study by the World Health Organization (WHO), according to experts, $23 \%$ of child deaths in the world are associated with changes in environmental factors, such as polluted air and water [11].

C. V. Alexeyev wrote: Undoubtedly, the proposed goals of education in the interests of sustainable development require public discussion, discussion and coordination. It seems promising to discuss these problems within the framework of the "Year of Sustainable Lifestyle" (UN). The goals of sustainable development are the priority directions of human development. Russia supports the sustainable development strategy and actively implements its main components - environmental, social and economic. Analysis of the impact of the components of sustainable development on the achievement of its goals allows us to state the following ratio: ecology: economy: society (society) $=28: 32: 40 \%$, or $1,0: 1,1: 1,4[12]$.

S. Ziyadin et al: The economic and mathematical models that form the basis of the toolkit are constructed using the mathematical apparatus of fuzzy logic, which allows for the description of poorly structured knowledge of specialists, as well as their application in solving questions about the extent of the impact of the proposed projects on the environment [13].

\section{Data and methodology}

\subsection{Data descriptions and analysis}

The environmental management system includes:

1. detailed development and adoption of the company's mission aimed at environmental protection;

2. analysis of the external and internal environment of the enterprise to clarify the environmental potential;

3. development of the company's goals and strategies to achieve its environmental mission.

Meanwhile, in order to implement an effective innovation policy, it is necessary to answer the logical question: what is the reason for the susceptibility of industrial corporations to innovation? The authors see the answer to this question in the analysis and systematic interconnection of factors influencing this complex process: a complex hierarchy of decision-making, lack of own funds at the level of centers of financial responsibility, high cost of innovations and weak state support, weak innovation potential and high risk of entrepreneurial initiative [14]. Among the most significant factors that an industrial corporation may face is the risk of loss of controllability, arising from the differences in the final goals of the executive services and top management of the corporation, and the pressure of random perturbations. From these positions, the advantages and disadvantages of the organizational and economic mechanism are studied, methods and 
models of management in an industrial corporation are being modernized, because they serve as indispensable tools in the intellectual system of corporate governance [15].

Table 1. SWOT - analysis of environmental management development on the global market.

\begin{tabular}{|c|c|}
\hline Strenghth & Weaknesses \\
\hline $\begin{array}{l}\text { - Availability of environmentally friendly } \\
\text { operations and goods, "green" image of the } \\
\text { company; } \\
\text { - Preparedness of working personnel to comply } \\
\text { with environmental regulations, rules and } \\
\text { standards; } \\
\text { - Research and development capability for the } \\
\text { development and use of the latest technologies; } \\
\text { - Safety for people and the environment. }\end{array}$ & $\begin{array}{l}\text { - the presence of "dirty" technology, poisonous } \\
\text { substances and toxins; } \\
\text { - Non-recyclable products and packaging; } \\
\text { - the purpose of making a profit at any cost. }\end{array}$ \\
\hline Opportunities & Treats \\
\hline $\begin{array}{l}\text { - the acquisition of new markets; } \\
\text { - development and promotion of } \\
\text { environmentally friendly products; } \\
\text { - maintenance of long-term time of stay of the } \\
\text { enterprise at the expense of structure of "green" } \\
\text { image; } \\
\text { - Preservation of resources and energy. }\end{array}$ & $\begin{array}{l}\text { - strengthening state control over compliance } \\
\text { with environmental legislation; } \\
\text { - The need for additional investment due to } \\
\text { stricter environmental standards; } \\
\text { - reduction of staff and personnel, as well as } \\
\text { scientists, due to market failures. }\end{array}$ \\
\hline
\end{tabular}

In recent years, there has been a trend of increasing numbers of visitors to protected areas in Georgia. According to the official data of the Agency for Specially Protected Natural Areas, while in 2007 the number of visitors to protected areas amounted to 7,714 thousand people, in 2017 it reached 952,672 thousand people [16]. The Ministry of Environment Protection and Agriculture reported that the number of visitors to Georgia's protected areas increased by $43 \%$ in January 2018 compared to the same month last year. $174 \sim$ The flow of visitors amounted to 16.5 thousand visitors, of which $54 \%$ are residents of the Georgian state and $46 \%$ are foreigners. [15].

The number of salvos at Klaus installations is also increasing (48 hours in 2017), with sulphur dioxide emissions increasing to $390 \mathrm{~g} / \mathrm{sec}$. (against 150-170 g/s in normal mode) (Fig.1).

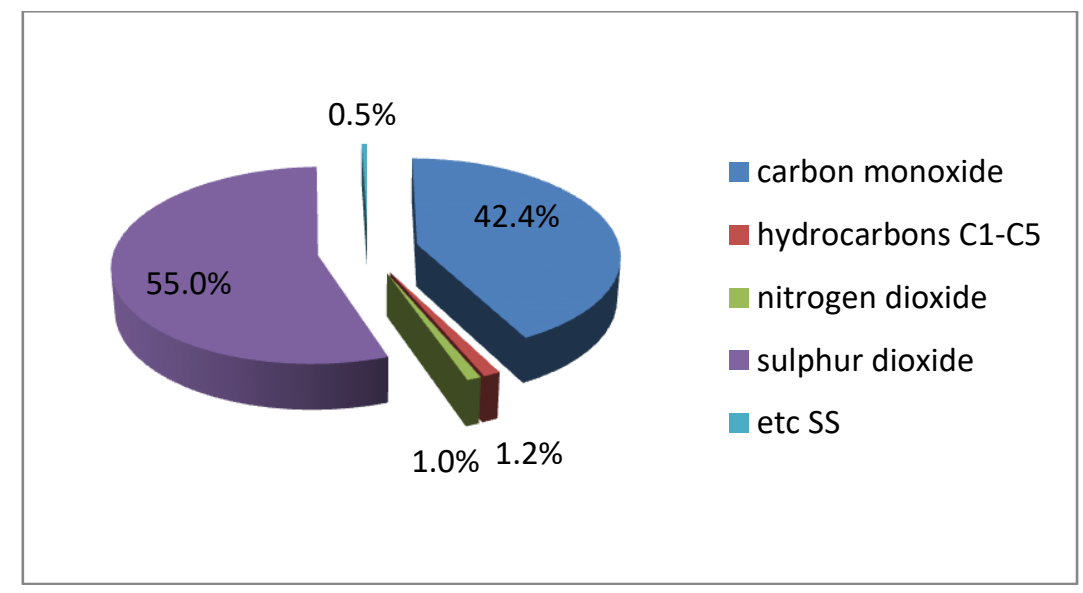

Fig.1. Structure of pollutant emissions at GTFs in 2017, \% [15]. 
This is the reason why sulphur dioxide emissions are growing every year due to the suboptimal operation of the Klaus-Sulphren plants, which account for $99.6 \%$ of the total GTF emissions. Sulphur dioxide became the main pollutant of the GTF and its total emissions in 2017 significantly exceeded the MPE level [17].

\subsection{Methodology}

In this context, the non-trivial behavior of competitors, consumers, and suppliers defuses the economic space, depriving it of predictability and reliability of communications, implies the construction, implementation, and development of an adaptive corporate management system. Equipped with analytical tools to monitor the market situation and proactive adequate response, the latter stabilizes the acceptable mode of operation of the corporation and removes from it the threat of crisis and bankruptcy. And since venture entrepreneurship is inherently risky and uncertain, it becomes a priority task to study and ensure the stability of industrial corporations in an outraged information and intellectual environment. Since the concept of economic sustainability is now interpreted in many ways, it is appropriate to clarify which of the authors follow. We will proceed from the natural-scientific interpretation of the property of sustainability and, taking into account the action in the environment of random factors, we believe that the economic system is sustainable if the following condition is met for the forward given $\varepsilon$, and any possible perturbations for this system: $(())(,,),), 0, \mathrm{P} Y \times x u R \times t t t t$ where $\mathrm{P}\{\}$ is the probability. In other words, if random perturbations affect the economic system, the probability that the condition of a limited change in the efficiency index will be met must be no less than some threshold value. At present, only a small share of industrial enterprises in our economy is engaged in intensive innovation activities. According to the official statistics, the innovation activity of organizations in terms of the share of organizations that carried out technological, organizational, and marketing innovations in the total number of surveyed organizations in the Russian Federation was $6.1-8.4 \%$ and $13.0-15.1 \%$ in terms of extractive industries and manufacturing industries in 2010-2017. The share of innovative goods, works and services in the total volume of goods shipped and works performed, which in the same years ranged from 2.7 to $7.2 \%$ and from 6.7 to $11.6 \%$, respectively, is even lower [9].

And now it is possible to analyze the development of environmental management by means of SWOT-analysis.

\section{Results and discussion}

Table 2. Ranking of the most attractive for the development of ecotourism protected areas in Georgia [18].

\begin{tabular}{|c|c|c|}
\hline Name & Square, hec & Quantity of ecotrop \\
\hline OOPT Tushveti & 83453 & 11 \\
\hline Vashlan sanctuary & 4864 & 7 \\
\hline OOPT Imertin caves & 504 & 3 \\
\hline
\end{tabular}

Thus, the following conclusions can be drawn from the results of the study:

1. There are 38 specially protected natural territories on the territory of Georgia (14 reserves, 10 national parks, 12 wildlife sanctuaries and 2 protected landscapes). The total area of specially protected natural areas is 511123 ha.

2. The most promising protected areas from the point of view of sustainable development of ecological tourism on the territory of Georgia are: Kazbegi National Park, Lagodekhi 
Nature Reserve, Mtirala National Park, Borjomi-Kharagaul National Park, Tbilisi Nature Reserve, Tusheti SPA and Imereti Caves SPA.

The maximum number of ecological routes (11 eco-trails) is developed in Tusheti protected areas.

4. Over the last five years, recreational activities in Georgia have started to develop actively, with visits to natural areas. The number of tourists from Russia increased by $35 \%$ between 2016 and 2017.

5. It is important to note that the venue of the fifth European Ecotourism Conference in September 2018 was Georgia [19].

Improvement of the tools used in the process of formation and development of environmental management systems and sustainable development of woodworking enterprises will contribute to increasing the efficiency of management through its rationalization and thus improve the environmental rating of the organization and products [20].

Making the appropriate calculations, it is possible to say with confidence about the expediency of this method of disposal. Total investments for dressing of wells from producing wells to injection wells will amount to 185 million rubles with daily volume of pumping 770 tons of $\mathrm{CO} 2$. This volume of pumping will allow to increase production of liquid hydrocarbons by 19.24 thousand tons. (or by $2.81 \%$ ), and the recovery factor - by $0.02 \%$. Injected gas will break through to the bottom-hole of gas production wells during the year, which will lead to an annual production growth of 163.97 thousand tons. Thus, the proposed measures will not only significantly reduce pollutant emissions into the atmosphere, but will also improve the economic performance of OOO Gazprom dobycha Orenburg [21].

\section{Conclusion}

The highest level of pollution and gradual reduction of natural resources, ineffective system of economic incentives for environmental activities - in many cases it will be easier for companies to pay fines than to solve environmental issues. The current reality shows that standardized environmental management has become a part of production processes. Because of this, environmental management is widely used in modern enterprises and most of them have set a goal to develop in the right direction in the future.

Application of different types of methods and types of environmental management will allow companies to be flexible in the changing conditions of the legislation and policy of the country in the field of environmental safety, as well as more effective in the organization of production processes and in the emergence of management structural complexes.

Concluding, we can say that environmental management systems are part of the current process of different enterprises of the Republic of Kazakhstan and allow them to develop in perfection. The current trends are demanding for unification of operations and their standardization to enter the world market, and the "quality premium" will allow companies to receive additional bonuses and profits through their active work.

\section{References}

1. T.G. Shelkunova, Rus. J. Ind. Econ. 4, 32-38 (2015) https://doi.org/10.17073/20721633-2015-4-32-38.

2. N. Natocheeva, T. Belyanchikova, Int. J. Mech. Engin. Tech. 10(2), 731-742. 
3. G. Mutanov, S. Ziyadin, A. A. Shaikh, Enterpren. Sustain. Issues, 6(4), 2136-2158 (2019) http://doi.org/10.9770/jesi.2019.6.4(41)

4. G. Mutanov, M. Milosz, A. Kozhanova, J. Engin. App. Sci. 13(10), 3396-3401 (2018)

5. S. Ziyadin, A. Madiyarova et al. J. Acad. Strat. Manag.17 (3) (2018)

6. S. Ziyadin, A. Omarova, R. Doszhan, G. Saparova, G. Zharaskyzy, Probl. Perspect. Manag. 16(4), 331-343 (2018)

7. O. P. Burmatova, Reg. Res. Rus. 5(3), 286-297. (2015).

8. Muzalevskaya, A. A., Sinel'nikova, V. N., \& Zabelina, A. A. Int. J. App. Basic Res. (43), 616-619 (2016)

9. L. H. Rieseberg, O. Raymond et al., Science, 301(5637), 1211-1216.

10. V. A. Sadovnichy, M. I. Panasyuk, et al. Solar Syst. Res, 45(1), 3-29 (2011)

11. S.A. Alexeeva, Bull. Mosc. Un. Econ. (4), 47-49 (2013)

12. S. Ziyadin, E. Streltsova, et al. Sustain. 11, 9, 2544 (2019)

13. M. Abdrakhmanova, G. Mutanov, Z. Mamykova, U. Tukeyev, Springer, Cham. 349359 (2018)

14. C. Sganzerla, C. Seixas, A. Conti, Proc. Engin 138, 64-71. (2016).

15. S. Ziyadin, Y. Gulmira, Econ. Annals-XXI, 5-6, 37-40. (2015).

16. O. Kalenov, S. Kukushkin,. E3S Web of Conferences, 41, 04025 (2018).

17. E. Vasilyeva, A. Mottaeva , E3S Web of Conferences, 91,08051, (2019) doi.org/10.1051/e3sconf /20199108051

18. C. Martinez-Fernandez, Serv. Indus. J. 30(1), 55-70. (2010)

19. N. A. Phelps, M. Atienza, M. Arias, Econ. Geogr. 91(2), 119-146. (2015)

20. D.Giurco, C. Cooper, Miner. Engin. 29, 3-12 (2012) 